\title{
Analisis Pendapatan dan Pertumbuhan Perekonomian Kota Bogor pada Tahun 2016-2020
}

\author{
Hery Haryanto, Yuni Nuraeni ${ }^{2}$, Martasya ${ }^{3}$, M Mardin Zen ${ }^{4}$ \\ Universitas Internasional Batam \\ hery.haryanto@uib.edu, 2041261.yuni@uib.edu, 2041090.martasya@uib.edu, \\ 1841298.mardin@uib.edu
}

\author{
*Corresponding Author \\ Diajukan : 20 Desember 2021 \\ Disetujui : : 1 Januari 2022 \\ Dipublikasi : 9 Januari 2022
}

\begin{abstract}
Income earned by an area in a certain time. The existence of income earned by an area at a certain time has an impact on economic conditions in the area. Bogor City is one of the regions in West Java Province with a fairly good economic movement in 2016-2020, it can be seen in terms of Regional Original Income (PAD) which decreased and increased from 2016-2020. This study will analyze the income received by the city of Bogor in 2016-2020, and will increase economic growth in the city. This study uses a quantitative method, where various data are taken from previous research and using data released by the Bogor City government in 2016-2020. This study found that Bogor City's income was quite good because it was able to increase PAD in 2019 and 2020. This result had an impact on Bogor City's economic growth which also increased. This study concludes that income and good economic development will have a good impact on a certain area for both infrastructure and non-infrastructure development.
\end{abstract}

Keywords: Income, Growth econimic Growt, PAD, Bogor City

\section{PENDAHULUAN}

Kemajuan lokal adalah bagian penting dari pergantian peristiwa publik. Perbaikan harus dilakukan sebanyak yang dapat diharapkan untuk membantu masyarakat secara umum. Manfaat melakukan pembenahan harus benar-benar diberikan kepada seluruh daerah, tidak hanya membidik sebagian dari manfaat melakukan pembinaan. UU No.32 Tahun 2004 dan UU No.33 Tahun 2004 yang mengatur sendiri penyelenggaraan pemerintahan lingkungan. Sejujurnya alasan mempertahankan kemerdekaan wilayah ini adalah untuk membuat pembangunan keuangan, kekuatan publik dan sirkulasi pembayaran yang setara. Strategi kemerdekaan teritorial dimaksudkan untuk mendesak pemerintah daerah yang dikelola negara untuk membuat pembangunan moneter dan penyampaian pembayaran yang adil antar daerah sesuai dengan kondisi lokal.

Kondisi dan kemungkinan moneter territorial merupakan modal dasar dan elemen yang berlaku dalam menentukan sistem strategi perbaikan keuangan daerah. Berbagai kondisi dan potensi hasil di setiap daerah menyebabkan metodologi pendekatan pemerintah daerah juga berbeda-beda. Seperti halnya kabupaten/kota di Provinsi Jawa Barat, sistem pengembangan keuangan diambil dan dijalankan dengan menciptakan habitat pengembangan moneter di setiap daerah. Bisa dikatakan bahwa Bogor mungkin adalah kota paling boros dengan keragaman sosial di Indonesia. Kota ini juga disebut kota hujan karena memiliki curah hujan yang lebih tinggi daripada komunitas perkotaan lainnya. Kota ini merupakan salah satu fokus negara Indonesia dan dikenal dengan sebutan Jabodetabek (Jakarta, Bogor, Tanggerang dan Bekasi).

Salah satu instrument untuk mengukur bantuan pemerintah terhadap jumlah penduduk di suatu ruang adalah dengan melihat PAD. Semakin tinggi PAD di suatu ruang, semakin baik pula 
derajat bantuan pemerintah daerah. Dan sebaliknya, semakin rendah PAD per kapita di suatu ruang, semakin rendah derajat bantuan pemerintah daerah (Asta, 2001). Cukai atau Pendapatan Asli Daerah merupakan pembayaran yang dimulai dari dalam daerah suatu daerah tertentu, yang dikumpulkan berdasarkan undang-undang yang berlaku. Oleh sebab itu pada penelitian ini akan menganalisis terkait pendapatan dan pertumbuhan Kota Bogor selama tahun 2016-2020.

Perumusan kebijakan yakni pengaruh tekanan-tekanan dari luar, kebiasaan lama, sifat-sifat pribadi, pengaruh dari kelompok luar, dan keadaan masa lalu. Informasi keuangan, analisa performa tiap bagian perusahaan, dan proyeksi pasar serta arus kas perusahaan juga memiliki peran dalam menentukan kebijakan perusahaan terkait. Berdasarkan pemaparan diatas, maka penulis tertarik untuk melakukan penelitian terkait "Analisis Produktivitas pada Pendapatan PT BMT Oppo Manufacturing Indonesia Terhadap Penjualan Smartphone Oppo Pada Tahun 2019$2021 "$.

\section{METODE}

Dalam melakukan analisis tentang pembayaran publik ini, dengan menggunakan strategi kuantitatif, yaitu siklus eksplorasi yang menggunakan angka sebagai alat untuk menguraikan apa yang perlu diketahui. Peneliti menggunakan informasi kuantitatif dalam menyelidiki pembayaran publik karena interaksi membutuhkan informasi sebagai angka, misalnya, efek samping dari estimasi pembayaran publik di Kota Bogor. Apalagi informasi tersebut digunakan sebagai informasi opsional yang didapat dari pihak berikutnya atau mencari informasi dari sumber, misalnya pemeriksaan majalah, artikel atau berita terkait. Selama waktu yang dihabiskan untuk pemeriksaan ini, pencipta menyelidiki dan mengumpulkan informasi dan membuat perkiraan yang nantinya akan mencapai penentuan tentang bagaimana dan apa pembayaran publik yang terjadi di kota Bogor, dan terlepas dari apakah ada efek keberuntungan atau ketidakberuntungan pada catatan tersebut.

Untuk informasi pembayaran Kota, peneliti mencari sumber yang dapat dipercaya, misalnya dari situs Badan Pusat Statistik, di mana peneliti menerima bahwa informasi di situs tersebut adalah informasi yang solid/dapat dipercaya tentang pembayaran kota di Indonesia.

Ragam informasi dimunculkan melalui eksplorasi dan konfirmasi situs-situs yang dapat diakses oleh kreator, sehingga kreator menjamin bahwa informasi dalam review ini asli dan dapat menjadi sumber yang solid. Sistem berikut adalah untuk memeriksa informasi yang dikumpulkan apakah tingkat pembayaran telah meningkat atau berkurang. Informasi yang dikumpulkan akan didistribusikan dalam buku harian dalam struktur polos atau tersusun.

\section{HASIL DAN PEMBAHASAN}

Berdasarkan hasil penelitian penulis, ada tiga hal pokok dalam pembentukan pendapatan daerah, yaitu pendapatan dari kekayaan daerah tertentu, uang perimbangan, dan pendapatan daerah lainnya yang sah. Penulis menganalisis bahwa pendapatan asli kota Bogor mengalami peningkatan dari tahun ke tahun, walaupun terjadi penurunan pada tahun 2018.

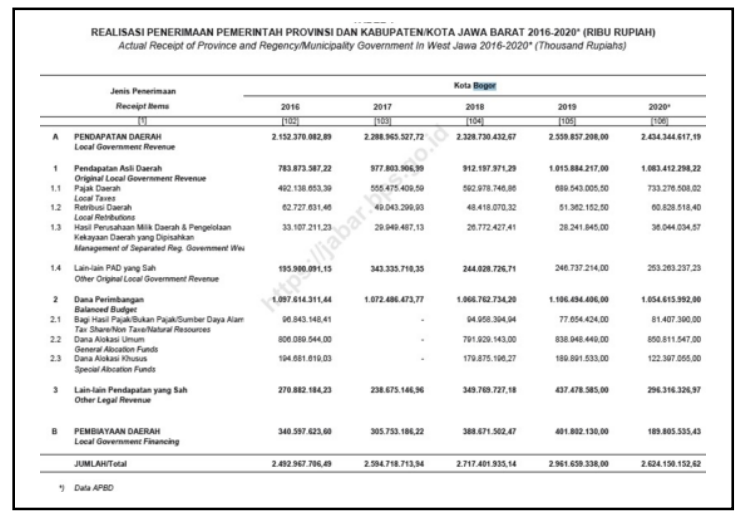

Gambar 1.Realisasi penerimaan pemerintah Kota Bogor, 2016-2020 
Pada tahun 2016-2019 pendapatan daerah Kota Bogor terjadi peningkatan yaitu pada tahu 2016 sebesar Rp2.152.370.082,89, pada tahun 2017 sebesar Rp2.288.965.527.72, pada tahun 2018 sebesar Rp2.328.730.432,67, dan pada tahun 2019 sebesar Rp2.559.857.208, namun terjadi penurunan pendapatan pada tahun 2020 yaitu sebesar Rp2.434.344.617,19. Walau demikian pertumbuhan pada pendapatan daerah Kota Bogor bisa dinilai baik karena terus terjadi pertumbuhan selama empat tahun yakni dari tahun 2016-2019.

Pendapatan Asli Daerah (PAD) Kota Bogor terjadi kenaikan dan penurunan sepanjang tahun 2016-2020, yaitu pada tahun 2016 sebesar Rp783.873.587,22, kemudian terjadi kenaikan pada tahun 2017 sebesar Rp977.803.906,99, dan terjadi penurunan padas tahun 2018 Rp9.12.197.971,29, kemudian terjaid kenaikan pada tahun 2019-2020, yaitu pada tahun 2019 sebesar Rp1.015.884.217.00, dan pada tahun 2020 sebesar Rp1.083.412.298,22.

Artinya perekonomian pada PAD dikategorikan baik walau pada tahun 2019-2020 terjadinya virus Covid-19, namun pemerintah Kota Bogor dapat meningkatkan PAD daerahnya. Hasil dari PAD didapat dari pajak daerah, retribusi daerah, hasil perusahaan milik daerah \& pengelolaan kekayaan daerah yang dipisahkan dan hasil dari PAD lain yang sah dan kemudian dijumlahkan maka diperoleh hasil PAD.

\section{KESIMPULAN}

Dilihat dari hasil kinerja Pemkot Bogor, kemungkinan terwujudnya PAD yang disahkan sangat mungkin terwujud. Pemerintah Kota Bogor tegas atas penilaian yang dipaksakan kepada wagraa kotanya agar bisa menjalankan kewajibannya kepada masyarakat. Penilaian negara akan digunakan untuk perbaikan negara. Usulan dan hal-hal yang perlu dipertimbangkan nantinya akan membantu pelaksanaan tahap penunjukan peluang pertukaran ke daerah dari tengah sehingga aset dapat dipindahkan dari tengah untuk melakukan latihan perbaikan di wilayah Bogor. Terlebih lagi, keuntungan yang bisa kita dapatkan akan cukup sering bekerja pada ekonomi dan bantuan pemerintah dari individu Kota Bogor.

\section{REFERENSI}

Asta, Mohamad. (2001). PDRB Kabupaten/Kota di Jawa Barat Tahun 1997-2000. Bandung: BPS Jawa Barat.

Ayumi, L. (2021). Simak Profil PajakKabupaten Berpenduduk https://news.ddtc.co.id/sim ak-profil-pajak-kabupaten-

Terbanyak di Indonesia. diindonesia-26834 berpenduduk-terbanyak-

Prasetya, E. R. (2018). Analisis Sektor Unggulan Perekonomian Di Kabupaten Bogor. Scientific Journal of Reflection, 1(4), 1-10. https://doi.org/10.5281/zenodo.1436986

Statistik, B. P. (2021). Persentase Penduduk Miskin (Persen), 2018-2020. https://bogorkota.bps.go.id/indicator/23/123/1/persentase-penduduk-miskin-.html Haryudi. (2020).

Pemkot Bogor Gelar Razia Pajak Kendaraan Besar-besaran. https://metro.sindonews.com/berita/1531081/171/pemkot-bogor-gelar-raziapajakkendaraan-besar-besaran

Statistik, B. P. (2021). Statistik Keuangan Pemerintah Daerah Provinsi dan Kabupaten/Kota di Provinsi Jawa Barat 2020, 2016-2020. https://jabar.bps.go.id/publication.html?Publikasi\%5BtahunJudu1\%5D=\&Publikasi\%5Bk ataKunci\%5D=statistik+penerimaan+\&Publikasi\%5BcekJudul\%5D=0\&yt0=Tampilkan

Syauqi, M., Siregar, H., \& Syaukat, Y. (2017). Strategy Increased Efficiency and Effectiveness of Bogor City Government Finance Performance in Managing the Budgetary of Regional 
Owner: Riset \& Jurnal Akuntansi

e-ISSN : 2548-9224 |p-ISSN : 2548-7507

Volume 6 Nomor 1, Januari 2022

Revenue and Expenditure PENDAHULUAN Paradigma pengelolaan keuangan daerah telah mengalami perubahan yang sangat mendasar sej. 9, 1-16.

The Ministry of Finance of The Republic of Indonesia. (2017). Sumary of the Local Government Budgets. 20. 